\title{
HGF Gene Mutation
}

National Cancer Institute

\section{Source}

National Cancer Institute. HGF Gene Mutation. NCI Thesaurus. Code C150638.

A change in the nucleotide sequence of the HGF gene. 